http://dx.doi.org/10.19183/how.21.1.16

\title{
The Exercise of Learner Autonomy in a Virtual EFL Course in Colombia
}

\section{Autonomía del estudiante en un curso virtual de inglés como lengua extranjera en Colombia}

\author{
Paula Andrea Bedoya \\ professeurcolombien@yahoo.fr \\ Universidad de Antioquia, Colombia
}

This case study explores how a group of graduate students manifest autonomy in an English as a Foreign Language virtual course at a Colombian university. Analysis of questionnaires, forums, and interviews showed that students manifested attitudes that led to autonomy such as motivation and commitment at the beginning of the course, but they also manifested high levels of dependence and lack of self-confidence. Later, they became more confident and performed more independently, two attitudes closely-related to autonomy. Furthermore, the results show that factors such as course design, the platform, and the teacher's role influenced the students' exercise of autonomy. Finally, the need for designing virtual English as a Foreign Language courses that promote autonomous learning and the teachers' and the students' roles in virtual environments are discussed.

Key words: Autonomous learning, EFL reading comprehension, learner autonomy, studentcentered instruction, virtual learning

En este artículo se describe un estudio de caso en el que se explora cómo un grupo de estudiantes de posgrado, de un curso virtual de inglés de una universidad colombiana, muestra su autonomía. La información se recolectó a través de cuestionarios, foros de discusión del curso y entrevistas. Al comienzo del curso, se encontró que los estudiantes manifestaron algunas actitudes relacionadas con la autonomía como la motivación y el compromiso. Sin embargo, también demostraron altos niveles de dependencia y falta de auto confianza. Más tarde, manifestaron seguridad e independencia, actitudes conectadas con la autonomía. Además, los resultados evidenciaron que el rol del docente, la plataforma y el diseño del curso influyeron en la autonomía del estudiante. Por último, la necesidad de diseñar cursos virtuales de lengua que promuevan la autonomía y los roles del estudiante y profesor en dicho ambiente de aprendizaje se discuten en este artículo.

Palabras clave: aprendizaje autónomo, aprendizaje virtual, autonomía del estudiante, comprensión lectora en inglés, enseñanza centrada en el estudiante

* Received: October 31, 2013. Accepted: March 11, 2014. 


\section{Introduction}

In the field of virtual education, the concept of autonomy has gained a very important place. Motteram (1997) claims that there has always been a recognized connection between educational technology and learner autonomy. Additionally, autonomy is seen as an essential quality for facilitating learning in both traditional and virtual education. The importance of autonomy in Computer Assisted Language Learning (CALL) is reported on by Benson (2001), who states that learners need a certain development of autonomy to use new technologies adequately.

In the last two decades, a number of technology-based projects have reported on the connection between CALL and autonomy. Figura and Jarvis (2007) examined the types of strategies students use and the extent to which learner autonomy is fostered when working with Computer-Based Materials (CBMs). They evidenced a good use of cognitive and metacognitive strategies among the participants. However, social strategies which involve interaction need to be fostered when teaching with CBMs. Ruiz (2005) reported on the design of a pilot application based upon Technology Applied to the Development of Learner Autonomy (TADLA), which promotes the development of attitudes associated with learner autonomy. Kourtis-Kazoullis (2008) carried out a study with immigrants who learned academic writing in Greek using Moodle. He showed how both guided and free writing activities of literary texts encourage students to express themselves, developing a voice in what they write, an ability which is highly related to autonomy (Pennycook, 1997). Fanany (2005) shared the experiences of an Indonesian program at Deakin University in converting four years of conventional tertiary Indonesian language material for online presentation. She found that online environments can maximize autonomous learning opportunities. Gonzalez and St. Louis (2008) illustrated how the integration of Web 2.0 tools in their classes increases learners' willingness to participate actively in their own learning process by making them aware of cognitive and metacognitive strategies. Other studies (Blin, 2005; Bordonaro, 2003; Healey, 2002; Sotillo, 2002) also reported on the connection between autonomy and CALL. All of them emphasize the importance of autonomy in language learning in virtual environments.

Concerning the study of autonomy in CALL in Colombia, there has been an increase of interest in this connection. Ardila and Bedoya (2006) reported on the inclusion of new Information and Communication Technology (ICT) in a contrastive grammar course at the undergraduate level. They found that the promotion of autonomous learning through the implementation of a Moodle platform in the course improved teachers' practices and facilitated students' learning process. Vargas, Cabrales, and Marrugo (2010) analyzed the influence of learning practices and independent assignments on the development of learner autonomy of an undergraduate program. They found that students' interest in both the 
program and the ICT is a factor that helps in the development of autonomy. Cuasialpud (2010) reported on an exploratory study on the experience of two indigenous students in a virtual English as a Foreign Language (EFL) course. They found that feelings of frustration and a lack of both motivation and autonomy affect learning. Finally, an empirical research project conducted by Cuesta (2010) discussed the design and implementation of online materials and emphasized the importance of their permanent assessment to be aligned with the instruction, students' motivation, and performance. This last study advocates the promotion of autonomy as one of the relevant features of online course materials.

The studies of autonomy in CALL carried out in Colombia remark on the importance of learner autonomy for students to succeed in language learning when studying in a virtual environment. Virtual courses seem to be increasing in number as an option to learn a foreign language; furthermore, strategies to promote autonomy through CBMs for learning appear to be a goal in virtual education. Some of the studies reported here evidence that students seem highly motivated when learning languages with computers. However, it is also found that students need more support to manage and take control over their learning in virtual environments. Therefore, it is necessary to continue examining students' levels of autonomy when studying in online environments to reflect on how teachers and administrators can improve these courses in order to promote autonomy in language learning.

This study intends to contribute to the field of autonomy in virtual education by analyzing not only students' manifestations of autonomy in a virtual reading comprehension course, but also the class conditions that affect students to manifest it. The research questions under investigation in this study read as follows: How do students manifest autonomy in a virtual EFL reading comprehension course? and, What factors are associated with these manifestations? The theoretical framework of this case study reviews the psychological notion of autonomy as proposed by Benson and Voller (1997) and the principles of connectivism which promote learning mediated by technology (Siemens, 2006). Adopting the constructivist perspective, I identify behaviors and attitudes related to autonomy that involve the concept of control over the learning process (Benson, 2010).

\section{Theoretical Framework}

One of the most significant contributions for the study of learner autonomy in language learning is provided by Benson and Voller (1997). They suggest that upon making connections between principles of knowledge, approaches to learning, and accounts of autonomy, the development of learner autonomy in language learning can be seen from three perspectives: technical, political, and psychological (Benson \& Voller, 1997). Since this study focuses on behaviors and attitudes related to cognition, it is rooted in the psychological notion of autonomy. 
From this perspective, the learner has the opportunity to choose what and how s/he wants to learn (Benson, 2001). Further, Benson (2001) claims that constructivism sustains versions of autonomy based on individual decisions concerning what and how to learn. From this perspective, autonomy is seen as a natural potential of the individual (Candy, 1989), and this potential is associated with the concept of self-direction, which is defined as the learner's general capacity to lead learning efficiently. However, the concept of autonomy goes beyond the concept of self-direction. Autonomy is related to singular, personal, and principled qualities connected with this capacity (Benson, 2001). This version of autonomy focuses on the learner's behavior, attitudes, and personality. As Little (1991) argues: "Autonomy is a capacity, for detachment, critical reflection, decision making, and independent action" (p. 4).

Some scholars defend the psychological version of autonomy. Schwienhorst (2008) claims that multi-user domain object-oriented (MOO), a virtual reality system in which several users are connected at one time adapted for educational purposes, provides the conditions to develop learner autonomy. This type of CALL offers the opportunity to foster experimentation, reflection, and interaction, which are key elements for autonomous learning. Little (2007) agrees with the constructivist perspective of autonomy and states that it provides learners with plenty of discourse initiatives that conventional pedagogies do not offer. Initiatives such as asking exploratory questions, making suggestions, challenging others' statements, and evaluating learning plans, tasks, and outcomes become important from this analytical angle. Deci and Flaste (1996) claim that "we are autonomous when we are fully willing to do what we are doing and we embrace the activity with a sense of interest and commitment" (p. 2). According to these constructivist authors, autonomy is implied in the learner's attitudes and behaviors. All these studies show how autonomy is highly related to the confidence of the individual, self-government and promotion of qualities in language learners (Benson \& Voller, 1997).

It seems that autonomy cannot be measured. It is not a quality students have or do not have. As Nunan (1997) puts it, "autonomy is not an 'all-or-nothing concept' but a matter of degree" (p. 192). Perhaps the clearer way to see how a student manifests autonomy is through certain visible behaviors associated with the broader construct of autonomy. Therefore, measuring autonomy tends to be irregular or variable. Benson (2010) finds that autonomy could be reflected in some perceptible behaviors and this implies that the student is in control of the learning process to some degree. According to Benson, it is through the idea of control, therefore, that researchers are apparently most able to assert the integrity of autonomy as a usable construct within language education research.

The idea of control over learning explained through the use of metacognitive, cognitive, social, and affective strategies is associated with autonomy. When a student self-monitors and self-evaluates his learning (Lai, 2001), when he manipulates learning materials and applies a specific technique to a learning task (O’Malley \& Chamot, 1990) or interacts with others to 
assist learning and regulates emotions (Oxford, 1990), he could manifest autonomy. In conclusion, from the psychological perspective, observable attitudes such as reflection, critical thinking, independent action, commitment, interest, and motivation could be seen as manifestations of learner autonomy.

\section{Connectivism for the Promotion of Autonomy}

Connectivism integrates principles of constructivism and the theory of chaos to describe learning in the digital era (Siemens, 2006). From this perspective, reality is undergoing permanent change, so knowledge and learning are continuously being transformed. These principles offer a whole new perspective for language teaching and learning in virtual environments as they are highly connected to the student-centered and context-based approach. Students are positioned as creators and transformers of knowledge, while learning is facilitated by technology (Siemens, 2006). From this approach, students count on a learning environment where autonomy is fostered while they develop emergent learning (Siemens, 2006). This involves high levels of cognition, reflection, and promotes innovation, capacities that are linked to the notion of autonomy described above.

When virtual courses adopt Web 2.0 tools such as wikis, blogs, interactive virtual platforms, and social networks, they may have the potential of enhancing collaboration, interactivity, and user-generated content, qualities that connectivism promotes (Pegrum, 2009). Furthermore, it is important to take into account the connectivist theory when designing and developing teaching programs for enhancing "communicative networking, community building, and identity negotiation" (Pegrum, 2009, p. 33), processes that favor learner autonomy and consequently emergence learning.

A virtual language course designed under the principles of connectivism could provide students with tasks that help them to reflect, express their points of view, make decisions, learn collaboratively, propose new alternatives to solve problems, and innovate using the language, manifestations associated with student autonomy. To sum up, the qualities students develop for learning in connection with connectivism are similar to those associated with autonomy and constructivism.

\section{Setting}

This study took place in a virtual reading comprehension course for graduate students from different programs at a public university in Colombia. Many graduate students take this course because they need to be certified as competent in reading comprehension, which is a requirement for graduation or to pursue their studies further. Also, they decide to take the virtual course because they are usually busy and cannot physically attend classes. 
This virtual reading comprehension course is developed in 120 hours through Moodle. The course was designed to teach reading comprehension from a structural view of language focusing on syntax and semantics. Most of the activities include identifying tenses and sentence structure, completing charts with the information of a text, identifying word categories, guessing the meaning of words, using their morphology, and inferring meaning from pictures or titles. Students also participate in forums, take a test at the end of each week and do the evaluation of the course. The purpose of the course is to provide graduate students with reading skills that allow them to interpret general and specialized texts.

Virtual reading comprehension courses in this program usually serve between 30 and 35 students. Most of the students who take the course work full time and have other subjects to study. Some groups are formed by people from all over the country and others from the same city where the university is located. When the latter is the case, students usually receive some orientation about the use of the platform in a face-to-face session before starting the course. Most of them do not have the basic computer skills at that point.

\section{Method}

To carry out this research, I used the case study approach. Creswell (2007) recommends this qualitative approach "to examine a case bounded in time and place, and look for contextual material time, from multiple sources of information to provide an in-depth picture of the case" (p. 96). Case study was the appropriate method to answer the research question, because a particular group was studied for three months whose members had all studied a specialization in law. They needed to meet the reading comprehension requirement to pursue their graduate studies. To conduct this research, I asked as required for the different permissions and informed all the participants about the purpose of this study. Data were collected through questionnaires, analyses of forums, and interviews.

A questionnaire was administered to the whole group in Moodle. Seventeen out of 36 students answered it. In this questionnaire, I attempted to have a description of students' performances in the course and identify manifestations of autonomy such as behaviors and qualities associated with this concept (Benson \& Voller, 1997) (see Appendix 1). Through the forums, I collected students' written texts such as their comments and questions. The purpose of this procedure was to identify students' behaviors linked to autonomy. I carried out a detailed search of attitudes reflected in their discourses, which were related to autonomy. For example, I identified how they experienced the learning process during the course as well as how they dealt with the technical problems and assignments.

I also conducted semi-structured interviews with seven students. They were chosen as a representative sample of the group taking into account their performances during the course. 
Two got high scores, two got low scores, while one quit the course after the first weeks and two were average students (see Appendix 2).

In the interest of generating useful data to the maximum, I also conducted an individual interview with the teacher of the course who had taught in the program for one year and a half. The purpose of this interview was to understand how the teacher defines her students in terms of autonomy, and from her perspective, how students manifested it (see Appendix 3). The interviews were conducted in Spanish and audio recorded.

I analyzed data using content analysis which is a research technique for making valid inferences from texts (Krippendorff, 2004). As a technique, content analysis provides current insights and expands the researcher's understandings of particular phenomena (Krippendorff, 2004). In this process, I recognized themes, coded and found connections. In the questionnaires, answers were classified into levels of frequency and treated in percentages, and then the results were compared with data from the forums and the interviews.

\section{Findings}

This section elaborates on the findings of this study. This includes evidences of how this group of students manifested autonomy or the lack of it in this virtual reading comprehension course and what factors influenced students positively and negatively along it. For the purpose of this section, I divide it into two topics. The first part illustrates the ways students developed and exercised their autonomy at the initial, middle, and last stage of the course. The second part presents the factors that affected students upon their exercise of autonomy in this virtual environment.

\section{The Exercise of Students' Autonomy Through the Development of the Course}

Insights from the data show that these students not only manifested some behaviors and attitudes associated with autonomy, but they also showed behaviors that could be related to the lack of it. Students' behaviors and manifestations of autonomy changed throughout the development of the course.

Initial stage of the course. Data from the forums indicate that at the beginning of the course students felt motivated to start the class, but expressed anxiety, fear of managing the platform, and difficulties in understanding assignments. In this initial stage, students demonstrated their interest and motivation when introducing themselves in the virtual forum. As one of the students manifested through the forum: "I want to learn and enjoy this course." However, while they felt motivated towards the class, they also felt worried and 
nervous about facing this experience. As the tutor stated in her interview: "They are frightened at the beginning, maybe because they are not getting used to working alone."

Yet, not only during the first week but also during the subsequent ones, students showed high dependence on the teacher's guidelines and support and exerted little autonomy. Besides the welcome and introduction messages, there were several messages asking for guidance. Data from the forum evidence that not only during the first week but also during the subsequent ones, most of the students showed high dependence. The following excerpt illustrates this: "I started to work, how should I continue? Should I follow the activities sequentially? How do I know?" (Student 1, Forum). Dependence on the teacher as scarce exercise of autonomy is found at this stage when students usually asked for guidance mainly in the first weeks when they were learning how to manage the platform. As claimed by one student: "I often wrote to the teacher when I had questions or problems, but it was more common at the beginning" (Student 7, Interview). Insights from interviews reveal that the students often needed the teacher's support, showing their dependence and thus making her the provider and the main character in the course.

To sum up, while students at this initial stage of the course manifested motivation and interest in learning English, they were very much limited by their scant computer skills and difficulties managing the platform, which led towards higher dependence on the teacher and scarce exercise of autonomy. Additionally, students proved not to have any control over the learning process; instead, the teacher was the one who controlled and led.

Middle stage of the course. The analysis of data from the interviews and the forums confirms that not only students continued to experience difficulties with the platform and the assignments, which resulted in high levels of dependence on the teacher, but also their exercise of autonomy was limited because of the multiple responsibilities students had outside the course. These multiple responsibilities were complemented by students' limitations in planning and managing their time, and by the number of assignments required in the course, which most of the students defined as excessive, considering their condition as graduate students and workers. For example, all the students expressed in their interview and some in the forum that they were very busy and had little time to study. They made a big effort to pass the course and felt that they had worked harder than they had in other subjects. That is the reason why most of them found this experience exhausting. An example of this is illustrated in the following excerpt: "I am a responsible person despite all my duties, but it was complicated for everyone, workshops with more than twenty questions, repetitive things, it was always our complaint" (Student 1, Interview).

Furthermore, it was found at this stage that many students not only resigned themselves to deal with the materials provided, but also asked other people to do assignments for them. For instance, five of the seven interviewees manifested that they often needed help from 
relatives, friends, and English teachers to understand texts and, sometimes, to do the assignments for them. This behavior reflects a certain lack of autonomy in the sense that these students were not self-conscious and responsible enough to do the course by themselves. Maybe they worried more about passing the course than about learning. Also, the lack of self-consciousness linked to the lack of autonomy is seen when students do not assume the role of active learners, when they show neither interest in learning nor dedication to take advantage of the course. When the interviewees were asked about what kind of help they received from others, they said that those people sometimes did the assignments for them. It would seem that the students of this group felt afraid or felt they were not able to do the activities alone or maybe they felt insecure and anxious as the teacher described them in her interview: "They are frightened, maybe because of the teaching system they are used to."

In summary, and as a consequence of a number of factors such as students' lack of time, number of assignments in the course, and difficulties with the platform, students in the middle of the course continued to display behaviors associated with dependency and not necessarily autonomy. At the same time, it was also found that some of the students asked others to do their assignments, a request which shows their many difficulties in dealing with the course duties by themselves.

Last stage of the course. Although some negative attitudes were identified in students not only at the beginning but also in the middle stage of the course, including high dependence on the teacher, difficulty with time management, lack of practice out of the course, and a difficulty to do assignments by themselves, by the end of the course students did indeed evidence a numbers of behaviors associated with autonomy in language learning. It was found in the forum that some students started to feel more confident in taking some risks and cooperating with others. They moved from interacting only with the teacher in the platform to communicating with their peers and supporting each other in the assignments. This excerpt cites a case in point: "She had the same doubt and the teacher had already answered me, so I asked her not to worry and be patient about the feedback" (Student 4, Interview).

Besides, the students showed evidence of monitoring their progress and using meta-cognitive strategies to improve their learning when writing in the forum to account for their progress, inform about the assignments they were doing, and express how they felt and what they had learned. The following excerpt exemplifies this: "I made progress, now I understand more and read faster" (Student 5, Forum).

As was clear in the analysis of the questionnaire and interviews, at this latter stage of the course, students had a better command over the platform and the course in general and this improvement allowed them to perform more effectively and behave more autonomously in different aspects. However, while students improved in many aspects and manifested their 
satisfaction with the course, they also agreed on stating that they preferred face-to-face instruction rather than virtual education courses as this type of modality more closely responds to their needs and possibilities as adults. Although the information gained from the questionnaire indicated that $93 \%$ of the group liked to study English in the virtual modality, in the interview, five of the seven students pointed out that they still preferred in-person rather than virtual courses. Most of them asserted that English should be learned face-to-face, especially to develop communicative skills. A clear example of this perception is the following: "Obviously in-person education is better since one is there with the teacher" (Student 6, Interview).

To conclude, by the end of the course some students showed behaviors associated with autonomy such as self-confidence, cooperation, and self-monitoring. On the other hand, even though they liked the course, some still prefer face-to-face instruction to virtual education.

\section{Factors That Affected Students for the Exercise of Autonomy}

The analysis of data from the questionnaire, the forums, and the interviews revealed some factors as possible constraints for students' manifestation of autonomy. These factors are related to the course design, the platform, and the role the teacher played.

Course design. Factors such as the length, the level of complexity, and the mechanical process of the assignments affected learner autonomy. This happened because the students were often limited to doing and submitting long reading comprehension exercises and multiple choice quizzes. Additionally, they found that there were a lot of assignments which tended to be repetitive and long; concerning this, the teacher argued: "They sometimes say that the course is pretty long, some say nothing and the few who participated said that there were many workshops to do" (Teacher's interview). Also, a student wrote in the forum: "To me the development of this module has been exhausting; I have spent almost three hours every day." The course design could be one of the factors that affect students' exercise of autonomy. It limited the students' opportunity to manifest this quality since they spent all their time doing long and traditional summative assignments, which did not imply reflection and decision making, among other attitudes related to autonomy.

The platform. Students' perceptions about the platform varied. Some students liked the platform while others did not. According to the questionnaire, $93 \%$ of the students reported that the platform was easy to use. Additionally, two of the seven interviewees claimed that they liked the platform and learned how to use it during the first weeks. In contrast, data from the interviews and forums showed that some students were not really satisfied with the platform. Five students expressed having faced some technical problems and pointed out that 
the platform was not practical enough. The following comment demonstrates this: "The platform was kind of inefficient, sometimes slow, there is a lack of functionality; we had to open and close windows for everything" (Student 2, Interview). Furthermore, in the forum there were many messages where students reported technical problems and asked for guidance concerning how to find a task, a link, an exam, or problems with a video. This message in the forum shows this: "I had a problem when playing the video, then the platform got blocked; I lost my first try to the test. Can you help me with this?" Thus, the teacher confirmed that students often wrote messages in the forum and through e-mail asking for guidance concerning how to manage the platform and deal with technical issues. She maintained: "one has to help them, if they ask for more time because of problems with the platform; one should extend the deadline and be flexible" (Teacher's interview).

To sum up, the platform did not favorably help students to count on an appropriate learning environment where autonomy could be manifested and developed. The type of assignments and the limited functionality of the platform limited students as to showing how autonomous they could be.

The Role the Teacher Played. Both the course design and the platform obliged the teacher to assume a central role in the course. The data from the forums reveal that the teacher always provided guidance and feedback to her students. For example, there was a big number of messages where she explained to students both assignments and linguistics features. Also, she gave them support when they had technical problems. In fact, the teacher was the participant who had the highest number of interventions in the forum. The following extract from one of her messages in the forum cites a case in point: "Hello Blanca, a noun does not have all the adjectives seen in the theory; the important thing is that when there are several of them in the same sentence, they must be placed in the right order." Although the teacher encouraged and supported her students during the entire course, her role was the one of a provider who had control of everything; in contrast, students assumed the role of receivers, who followed instructions and submitted assignments. They had no control over what and how to learn, because everything was already chosen affecting their exercise of autonomy.

On the other hand, the design, the pre-established assignments, and the limited web 2.0 tools available on the platform limited both the teacher and the students to position themselves in a suitable and active role. Activities such as completing charts with the information of a text, multiple choice and cloze exercises, identifying word categories in a text, and inferring meaning from pictures or titles forced both the students to answer questionnaires and the teacher to check and send feedback. Therefore, the structure of the course did not allow the students to be active performers, because they could not decide on the content, the tasks, and the evaluation. 


\section{Discussion}

In this discussion I reflect on the role of virtual platforms and the tutor to enhance learner autonomy. Also, I analyze how students' perceptions toward virtual education influence the exercise of autonomy.

\section{Virtual Courses Designed to Enhance Learner Autonomy}

It is clear from the study that students did not have the opportunity to take control over the content, the methodology, and the evaluation of the course, actions that could include students in decision making and the development of autonomy (Rivers, 2001). The findings show that neither the teacher nor the students participated in the construction of the syllabus. In contrast, all the tasks were established in advanced without any negotiation among the parts. Therefore, the course did not take into account students' needs, interests, background, and capabilities, but it imposed a syllabus. That is why many of these students think that the course was just a requirement to pursue graduate studies, a course that demanded much from them because of its complexity and length; features that caused them stress and anguish.

This study confirms the necessity to review teaching pedagogies in favor of learner autonomy in the virtual context. If educational administrators are aware of the students' role in virtual education and provide them with the elements with which to learn by themselves, they might have more opportunities to exercise autonomy and learn in the way they choose. If a language course is designed under the constructivist notion of autonomy, students may count on an environment wherein they could manifest attitudes and behaviors linked to autonomy such as self-direction (Rivers, 2001), critical reflection, motivation (Deci \& Flaste, 1996), decision making, independent action (Little, 1991), self-confidence and self-government (Benson \& Voller, 1997). An example of this is seen when a virtual course provides students with e-learning activities and web 2.0 tools that could facilitate interaction, socialization, connection making, and reflection, qualities associated with connectivism. A course where students are only asked to do and submit assignments does not open possibilities to interact and construct knowledge. It is necessary that virtual language courses equip students with a methodology which involves decision making, critical thinking, and community building.

It would be interesting to include connectivism in the construct of virtual courses. In the case of language learning, a virtual course designed under the principles of connectivism could empower students to make decisions and transform reality (Siemens, 2006). Thus, students may be encouraged to reflect, make connections, create, and communicate using technology (Siemens, 2006). However, as seen in this case, students could not develop such qualities or abilities while doing assignments and practicing the language. In contrast, they were limited to answering questionnaires and interpreting texts. 
To sum up, virtual language courses need to be designed with multiple options and tasks that enhance reflection and language production. Also, they need to target all learning styles and considerably meet students' needs and interests in order to encourage them to learn in the way they choose i.e. promoting creativity and decision making. In this course, students did not have the chance to decide on the topics they wanted to read. In contrast, they were assigned topics and tasks under the assumption that they all had the same language proficiency level, interests, and needs. Perhaps they would have been more interested in learning English online if the readings provided had been more attractive to them and adapted to their language level since the findings show that most of the students complained about the level of complexity and length of the tasks. This study reveals a higher need of reflecting and planning when designing virtual language courses. In this process, it is important to focus on proposing activities and tasks that promote the development of reflection, self-government, decision making, collaboration, and creativity, among other qualities related to constructivism and connectivism.

\section{Teacher's Role for the Promotion of Learner Autonomy}

This study reveals that the teacher played the role of a provider who supported students with all the guidance they needed and encouraged them to succeed. However, the way the course was designed resulted in her being the only one who took control of the content and the evaluation. The teacher was forced to exclude students when making decisions; in contrast, they were assigned tasks and imposed deadlines when submitting tests. When the teacher is the one who controls everything as is seen in this study, opportunities for students to exercise autonomy are very scarce since they cannot make choices concerning what and how to learn. Teachers and course designers who do not create opportunities for helping students think, interact, and construct using the foreign language reflect learning assumptions far from autonomy, since they still want to take control over students' learning.

Teachers and course designers should adopt a student-centered approach in the design of the virtual learning environment in order to position students as the main characters in the process. Virtual teachers need to be aware of students' backgrounds and individual differences that influence the way they learn; hence, courseware materials must be varied and adjusted to students' needs. An autonomous teacher should promote students' development of mental capacities such as reflection, critical thinking, and self-government, capacities that are associated with autonomy. Therefore, the teacher should consider the design of an online environment whereby students feel they make both choices and decisions about what and how they want to learn (Benson, 2001). For instance, the teacher can propose that students design a learning plan where they decide what topics they want to study and the deadlines to submit evidences of learning. Also, the teacher can provide a list of topics and tasks where 
students can choose the ones they like the most and work on developing the same language skills in different ways.

Besides the need of adopting a student-centered approach in virtual language courses for the development of autonomy, it is important that virtual teachers abandon some prejudices about online education. As was found in this study, the teacher expressed that her students needed her guidance and support all the time. Moreover, she argued that they were sometimes unable to succeed by themselves and depended a lot on her supervision. Some teachers that work in virtual environments need to put aside prejudices about virtual education and open their minds to thinking that English can be learned in the virtual modality. Despite the fact that this study shows that most of the students believe that English may be learned through face-to-face instruction better than online, teachers should be convinced that this second modality can also be effective, since many successful experiences have reported that students can learn through the use of ICT and virtual environments. A current problem in our context is that some teachers still believe that it is harder for students to learn a language in a virtual course than in a face-to-face one. Therefore, they may become affected and predisposed by this assumption and they could perpetuate these kinds of beliefs onto their students.

\section{Students' Perceptions Towards Virtual Education and Their Influence on Student Autonomy}

This case study shows that although some students manifested through the questionnaire and the forums that this virtual course was good and interesting, most of them still believe that face-to-face instruction is a better option for learning a language. Additionally, they still believe that the teacher is the main character of the scene and that learning depends a lot on $\mathrm{him} /$ her. Some students believe that the role of the teacher is critical for them to engage in learning; and as the tutor stated, they felt alone in some way in the virtual context, so they assumed that learning a language through a virtual environment is harder than learning in a face-to-face course.

Students also have the same challenging role in both face-to-face and virtual education. They need to position themselves as the main characters in their learning process. It is still seen that students in both traditional and virtual classes hold the teacher responsible for learning. The learning process, according to them, needs to be led by the teacher who has control over everything. Both modalities of instruction should promote students' empowerment. Here they must have opportunities to make choices and learn what they want and how, and this is what autonomy is about. In virtual learning environments, language students should be encouraged to plan, monitor, and evaluate their process, all those meta-cognitive strategies (O’Malley \& Chamot, 1990). Lai (2001) states that such strategies are processes of control. The nature of the virtual context should demand that students create 
or develop strategies for their learning. It is supposed that they are the ones who decide when and how to study. Therefore, it is a way to show how they can take control over their learning.

\section{Conclusions}

This study aimed at examining how a group of graduate students manifest autonomy in a virtual reading comprehension course at a public university. The results of this study indicate that the students manifested attitudes and behaviors associated with both autonomy and a lack of it. In other words, it was seen that most of them showed attitudes that lead to autonomy such as motivation and commitment at the beginning, but they also manifested high levels of dependence and a lack of self-confidence. Later, they became more confident and performed more independently at the end of the course, two attitudes close to autonomy. On the other hand most of the students maintained their preference for learning English in face-to-face instruction because they considered it more efficient due to the teacher's physical support. It can be concluded that the findings demonstrate that these students have not believed yet that a foreign language can be learned through the virtual modality. They think that a lot of responsibility and commitment are needed to succeed in a virtual language course and they do not feel prepared to face this challenge.

There is still much left for future researchers to investigate. A direction worth pursuing for future research is to see how virtual language courses can be designed while breaking the traditional model of assigning and submitting activities. Instead, it is necessary to build a methodology where interaction, reflection, and creativity enhance the development of autonomy which, in turn, facilitates learning.

\section{References}

Ardila, M. E., \& Bedoya, J. R. (2006). La inclusión de la plataforma de aprendizaje en línea MOODLE en un curso de gramática contrastiva español-inglés [The inclusion of the online learning platform MOODLE in a contrastive grammar course]. Íkala, Revista de Lenguaje y Cultura, 11(17), 181-205.

Benson, P. (2001). Teaching and researching autonomy in language learning. Harlow, UK: Pearson Education.

Benson, P. (2010). Measuring autonomy: Should we put our ability to the test? In A. Paran \& L. Sercu (Eds.), Testing the untestable in language education (pp. 77-97). Reading, UK: University of Reading.

Benson, P., \& Voller, P. (Eds.). (1997). Autonomy and independence in language learning. London, UK: Longman.

Blin, F. (2005). CALL and the development of learner autonomy: An activity theoretical study (Unpublished doctoral dissertation). The Open University, United Kingdom. 
Bordonaro, K. (2003). Perceptions of technology and manifestations of language learner autonomy. CALL-EJ Online, 5(1). Retrieved from http://callej.org/journal/5-1/ bordonaro. html

Candy, P.C. (1989). Constructivism and the study of self-direction in adult learning. Studies in the Education of Adults, 21(2), 95-116.

Creswell, J. W. (2007). Qualitative inquiry and research design: Choosing among five approaches. London, UK: Sage Publications.

Cuasialpud, R. E. (2010). Indigenous students' attitudes towards learning English through a virtual program: A study in a Colombian public university. PROFILE Issues in Teachers' Professional Development, 12(2), 133-152.

Cuesta, L. (2010). The design and development of online course materials: Some features and recommendations. PROFILE Issues in Teachers' Professional Development, 12(1), 181-201.

Deci, E. L., \& Flaste, R. (1996). Why we do what we do: Understanding self-motivation. New York, NY: Penguin Books.

Fanany, R. (2005). Autonomous learning through online teaching. PacCALL Journal, 1(1). Retrieved from http:// citeseerx.ist.psu.edu/viewdoc/download?doi=10.1.1.117.9652\&rep= rep1\&type $=$ pdf

Figura, K., \& Jarvis, H. (2007). Computer-based materials: A study of learner autonomy and strategies. System, 35(4), 448-468.

Gonzalez, D., \& St. Louis, R. (2008). The use of Web 2.0 tools to promote learner autonomy. Independence, 43, 28-32. Retrieved from http://peoplelearn.homestead.com/MEdHOME2/Technology/ WebToos.2.0.autonomy.pdf

Healey, D. (2002). Learner autonomy with technology: What do language learners need to be successful? TESOL 2002, CALL-IS Academic Session.

Kourtis-Kazoullis, V. (2008). From theory to practice: The creation of an internet-based language learning environment for academic language proficiency in Greek as a second language. Innovation in Language Learning and Teaching, 2(3), 289-301.

Krippendorff, K. (2004). Content analysis: An introduction to its methodology. London, UK. Sage Publications.

Lai, J. (2001). Towards an analytic approach to assessing learner autonomy. The AILA Review 15, 34-44.

Little, D. (1991). Learner autonomy: Definitions, issues and problems. Dublin, IE: Authentik.

Little, D. (2007). Language learner autonomy: Some fundamental considerations revisited. International Journal of Innovation in Language Learning and Teaching, 1(1), 14-29.

Motteram, G. (1997). Learner Autonomy and the Web. In V. Darleguy et al. (Eds.), Educational technology in language learning: Theoretical considerations and practical applications (pp. 17-24). Lyon, FR: INSA.

Nunan, D. (1997). Designing and adapting materials to encourage learner autonomy. In P. Benson \& P. Voller (Eds.), Autonomy and independence in language learning (pp. 192-203). London; UK: Longman. 
O'Malley, J. M., \& Chamot, A. U. (1990). Learning strategies in second language acquisition. Cambridge, UK: Cambridge University Press.

Oxford, R. L. (1990). Language learning strategies: What every teacher should know. Boston, MA: Heinle \& Heinle.

Pegrum, M. (2009). Communicative networking and linguistic mashups on Web 2.0. In M. Thomas (Ed.), Handbook of research on Web 2.0 and second language learning (pp. 20-41). Hershey, NY: Information Science Reference.

Pennycook, A. (1997). Cultural alternatives and autonomy. In P. Benson \& P. Voller (Eds.), Autonomy and independence in language learning (pp. 35-53). London, UK: Longman.

Rivers, W. P. (2001). Autonomy at all costs: An ethnography of metacognitive self-assessment and self-management among experienced language learners. The Modern Language Journal, 85(2), 279-290.

Ruiz, M. N. (2005). Learner autonomy in computer-assisted language learning: A comparative case study of learners' behaviors in the English as a foreign language context (Unpublished doctoral dissertation). Universitat Jaume I, Spain. Retrieved from http://www.tdx.cat/handle/10803/10440

Schwienhorst, K. (2008). CALL and autonomy: Settings and contexts variables in technology-enhanced language environments. Independence, 43, 13-15.

Siemens, G. (2006). Knowing knowledge. Retrieved from http://www.elearnspace.org/ KnowingKnowledge_LowRes.pdf

Sotillo, S. M. (2002). Constructivist and collaborative learning in a wireless environment. TESOL Journal, 11(3), 16-20.

Vargas, M., Cabrales, J., \& Marrugo, I. (2010). La autonomía en el aprendizaje del inglés y su relación con los trabajos independientes asignados a los estudiantes [Autonomy in English language learning and its relationship to students' independent assignments]. Íkala, Revista de Lenguaje y Cultura, 15(26), 119-150.

\section{The Author}

Paula Andrea Bedoya works as a teacher and researcher at Universidad de Antioquia (Colombia). She holds a Master's in foreign language teaching and learning from the same university. 


\section{Appendix 1: Students' Questionnaire ${ }^{1}$}

\section{Dear graduate students:}

In this questionnaire you will answer some questions related to your role as a virtual student of the reading comprehension program.

Check the level of frequency for each activity

\begin{tabular}{||l|l|l|l|l||}
\hline & Always & Sometimes & Seldom & Never \\
\hline I plan the time for studying in this course. & & & & \\
\hline I submit assignments on time. & & & & \\
\hline I self-assess my performance in the course. & & & & \\
\hline I reflect on what I learn. & & & & \\
\hline I interact with my classmates. & & & & \\
\hline I am interested in the teacher's feedback. & & & & \\
\hline $\begin{array}{l}\text { I spend enough time working on the } \\
\text { course during the week. }\end{array}$ & & & & \\
\hline $\begin{array}{l}\text { I study English on my own (additional to } \\
\text { the course). }\end{array}$ & & & & \\
\hline I am able to work alone. & & & & \\
\hline I manage my time while I take the course. & & & & \\
\hline I ask the tutor when I need clarification. & & & & \\
\hline I express opinions through the forum. & & & & \\
\hline $\begin{array}{l}\text { I think I have achieved my objectives in } \\
\text { this course. }\end{array}$ & & & & \\
\hline I think I am committed to the course. & & & & \\
\hline I have a good opinion of the course. & & & & \\
\hline \hline
\end{tabular}

1 The questionnaire was translated; the original version was in Spanish. 


\begin{tabular}{|c|c|c|c|c|}
\hline & Always & Sometimes & Seldom & Never \\
\hline \multicolumn{5}{|l|}{ I like to study English online. } \\
\hline \multicolumn{5}{|l|}{ I need the teacher's support to learn. } \\
\hline \multicolumn{5}{|c|}{$\begin{array}{l}\text { I have needed a classmate's help to do the } \\
\text { activities. }\end{array}$} \\
\hline \multicolumn{5}{|l|}{$\begin{array}{l}\text { What I have learned in this course has } \\
\text { been useful. }\end{array}$} \\
\hline \multicolumn{5}{|c|}{$\begin{array}{l}\text { I have given suggestions for improving the } \\
\text { course. }\end{array}$} \\
\hline \multicolumn{5}{|c|}{$\begin{array}{l}\text { I understand assignments on the platform } \\
\text { easily. }\end{array}$} \\
\hline \multicolumn{5}{|l|}{$\begin{array}{l}\text { I search information on the Internet for } \\
\text { learning. }\end{array}$} \\
\hline \multicolumn{5}{|l|}{$\begin{array}{l}\text { I can control my emotions related to } \\
\text { learning. }\end{array}$} \\
\hline \multicolumn{5}{|l|}{$\begin{array}{l}\text { I feel confident about my performance } \\
\text { during the course. }\end{array}$} \\
\hline \multicolumn{5}{|l|}{ I identify my learning difficulties. } \\
\hline $\begin{array}{l}\text { I can control my attention when I am } \\
\text { taking the course. }\end{array}$ & & & & \\
\hline
\end{tabular}




\section{Appendix 2: Students' Interview ${ }^{2}$}

This appendix shows the questions used in the semi-structure interview for the students About the course:

1. What can you say about this reading comprehension course?

2. What was your goal in this course?

About autonomy:

3. Learning in a virtual course requires time management. How do you rate yourself related to this?

4. It also implies independent work. It means going beyond the activities proposed in the course. How was your performance concerning this?

5. It is assumed that an autonomous student does not need the teacher's supervision to work during the course. How did you see yourself and the group regarding this?

6. An autonomous student communicates and cooperates with others for learning. How was your performance in this aspect?

7. How was your performance comparing the first weeks and the last weeks of the course?

8. To what extent was the course beneficial for you?

9. What do you think about learning English in the virtual modality? Compare face-to-face instruction with virtual instruction.

2 This interview was translated from Spanish. 


\section{Appendix 3: Tutor's Interview ${ }^{3}$}

1. When did the course start and finish?

2. How many students did you have in this course?

3. What did you know about your students' backgrounds?

4. How many students passed and failed?

5. Do you know why some students quit?

6. What kind of comments did the students write in the forum? How often did they participate?

7. Did they suggest anything to improve the course?

8. What would you say about your students? Who are they?

9. Did your students ask for extra material?

10. What was the students' opinion of the course?

11. Did the students communicate among themselves?

12. Did students do assignments on time?

13. What did the students think about the platform?

14. Was it easy for them to understand instructions on the platform?

15. Do you think your students were independent or they needed permanent supervision and support?

16. Did your students manifest any discrepancy with the course?

17. Do you know if your students identified their learning difficulties? Did they express their weaknesses?

18. What emotions did you find in your students' messages? (anxiety, calmness, gratitude)

19. Do you know if your students used English in other contexts different from the course?

20. Did your students take the initiative sometimes?

3 This interview was translated from Spanish. 